\title{
Transformation of Traditional Arts Performances as Cultural Tourism Attraction: Case Study of Saung Angklung Ujdo
}

\section{Priyanto, Heri Yuliyanto, and Budiman Mahmud Musthofa}

Tourism Laboratory, Vocational Education Program, Universitas Indonesia

\section{Abstract}

In the current era of globalization, tradition arts performing needs the attention of various parties. It is related to the principle of preservation of cultural traditions, that is, the tradition arts performing should still be preserved. At the same time, globalization so powerfully grinds the tradition arts performing. One of the effects of globalization in the field of tourism was marked by the exploration of cultural tourism attractions including the tradition arts performing. The alternative solution to these problems

Corresponding Author: Priyanto

Received: 8 June 2018 Accepted: 17 July 2018 Published: 8 August 2018

Publishing services provided by Knowledge $\mathrm{E}$

(a) Priyanto et al. This article is distributed under the terms of the Creative Commons

Attribution License, which permits unrestricted use and redistribution provided that the original author and source are credited.

Selection and Peer-review under the responsibility of the 2 nd ICVHE Conference Committee. is cultural adaptation (adaptation of tradition arts performances) in accordance with the demands of time, but without compromising the essence of it. This article aims to describe how the transformation of the traditional art performances at Saung Angklung Udjo presents as the attraction of cultural tourism that attracts tourists. A qualitative approach is used to analyze the topic through the performing observation and deep interview to get the information and data. The results showed that Saung Angklung Udjo has made changes to the tradition arts performing as being one of the attractions that attract cultural tourism by working on some of the components and the basic elements of the performance. Tradition arts performance at Saung Angklung Udjo is relatively simple, densely packed, entertaining, and interactive without losing the essence of the tradition arts performance. It is one of the alternative attractiveness of cultural tourism that supports the tourism industry.

Keywords: tradition arts performance, cultural tourism, Angklung, Saung Ujo

\section{Introduction}

Globalization is happening today have a negative impact on the existence of culture. Cultural globalization and the rapid flow of changes and the influx of foreign culture have impacts on the existence of local culture [1]. Some studies indicate that the globalization that struck Indonesia today led to more abandonment of traditional arts 
arts Ludruk [4] even according Chairman of the Forum Cultural Park in Indonesia Ikke Dewi Sartika in West Java there were at least 43 endangered traditional arts [5]. Various issues such as the aforementioned should be a serious concern by all elements of Indonesian society, so the impact of cultural globalization that has occurred does not worsen the situation further adds.

The success of the change in the traditional arts Saung Angklung Ujo (SAU) into performance arts that became one of the tourist attraction is interesting to observe. SAU has managed the creation of the art performing arts traditions of angklung be interesting and kept referring to the tradition. Even also has managed to preserve, develop and create other traditional arts.

SAU have been made by Udjo Ngalagena (Mang Udjo) in 1966 is one manifestation of the development of traditional angklung art, especially in the field of production, education and performances. At first, Ujdo Ngalana develop Sundanese traditional music. Traditional music does not mean that a music and a variety of elements in it is old-fashioned, old-fashioned or outmoded. However, traditional music is music that is unique and reflects the culture of an ethnic or community. Traditional music is music that is rooted in the tradition of a particular society, then its survival in the present context is an attempt to inheritance hereditary previous community for the community next.

In the SAU Journey, not only traditional music are growing up, but also the various elements of traditional art have appeared. The arts performance include helaran, puppet show, angklung mass, arumba (Alunan Rumpun Bambu), angklung orchestra, traditional dance (Mask dance, and Peacock dance), etc.

In the 1960s, Udjo Ngalagena develop the game angklung based tunings pelog, salendro, and madenda. Udjo started to teach how to play angklung to many people from various communities and in 1966 founded the SAU Udjo. In 1968, the Minister of Education and Culture set angklung music as an educational tool in schools. Since then, angklung into teaching materials in various levels of education in Indonesia, especially in West Java. On November 16, 2010, 44 years after SAU stands, angklung set as The Representative List of the Intangible Cultural Heritage of Humanity (Masterpieces of the Oral and Intangible Heritage of Humanity) by UNESCO in the trial to the 5th Intergovernmental Committee of UNESCO in Nairobi, Kenya. SAU's success, has brought a worldwide tradition art angklung received an award from UNESCO on 16 November 2010 and set a Tradition Art Angklung as a World Cultural Heritage (The Intangible Heritage). 
Various studies focused on the SAU has been done, particularly related to the study of tourism, education, arts and culture [6-8]. Likewise Dr. Budiman M.M., he explored about SAU through their dissertation that entitled 'The creativity Udjo Ngalagena: Study Success Creativity Development Saung Angklung Udjo'. However, especially in terms of the transformation of traditional performing arts as a cultural tourism appeal case studies Saung Angklung Udjo no one has addressed specifically and depth [9]. Therefore in this study will attempt to assess and raised on these issues.

The purpose of this study is describing of the performing arts activities that took place at Saung Angklung Udjo that including production, optimization and creation that has been done so that it can and managed to become one of the alternatives of cultural tourism appeal. Based on the aforementioned description, this research question is 'How does the transformation of traditional arts performances at SAU packed into an interesting art show and the main attraction of cultural tourism?'. Sub research question is

- Art show what are the different SAU?

- How SAU resemble the traditional art performances transformation into an interesting art show and become cultural tourism destination?

To answer these problems, the authors will assess in advance the presence of SAU with all its activities and various other things that support the discussion.

\section{Literature Study}

\subsection{Arts concept}

Art can be defined in terms of beautiful things or nice things. Some sense associated with art submitted by art experts. According to Ki Hajar Dewantara art is any human action arising out of life and is a wonderful feeling, to be able to move human feelings. Thomas Munro said that art is a tool of man-made humans to cause psychological effects on other people who saw it. The effects include tangible responses observation, recognition, imagination, rational and emotionally. Meanwhile, in the opinion of encyclopedia art is everything that people do not at the instigation of their basic needs, but is what is done solely for the will to be luxury, pleasure, or for encouragement to the spiritual needs.

In the concept of art there is a term of art tradition. Some experts argue that the tradition of Art is a manifestation of creativity, taste and human initiative that has 
various functions for society [10] and in its development can be an income generator for the community $[11,12]$. Traditional arts in general can be either as (1) a traditional art ritual for religious ceremonies and customs, and (2) the tradition of art specially packaged for the public and enjoyed by tourists $[13,14]$.

In addition, in the concept of art is also familiar with the term of art performances. Performance art is art in which the actions of individuals or groups in a particular place and at a particular time is a job [15]. It can happen anywhere, anytime, or for a long time. Performance art can be any situation that involves four basic elements are: time, space, the body of the artist and the relationship between performer and audience.

In the process of the performance include the essential elements that must exist, namely players (performer), audience (audience), message (idea). All three are interwoven or interaction that a deliberate and conscious.

Indonesia is very rich with a variety of performing arts. Including the types of performing arts among which are dance, music, opera, drama. There are several components in the performing arts which are the source of the story, the creators, actors, stage/point presentation, property, spectators, management

\subsection{Tourism concept}

Etymologically, the word 'pariwisata' comes from the Sanskrit that consisting two syllables: (a) 'Pari' means many, many times, circling. (b) 'wisata' means traveling, traveling. So the word is defined as tourism trips made repeatedly or circling from one place to another. To clarify, it can be concluded the definition of Tourism is a journey that is done for a while, which was held from one place to another with the intent not to try (business) or make a living in the places visited, but simply to enjoy the journey to sightseeing and recreation or to meet the diverse desires.

Robert Melntosh and Shasikant Gupta tried to reveal that tourism is a combination of symptoms and relationships that arise from the interaction of tourists, businesses, local governments and host communities in the process of attracting and serving tourists as well as the other patrons [16].

While the definition of rating by G. A Schmoll is an individual or group of individuals who consider and plan its purchasing power for recreation and leisure trips, who are interested in the trip is generally motivated by a trip he'd ever done, increase knowledge, attracted by the services provided by a tourist destination areas that can attract visitors in the future. 
Tourist is any person who travels from his residence to visit other places to enjoy the trip and visit it (Inpres RI No 9 Th 1969). The characteristics of a person that can be called as tourists are: a. The trip was made more than 24 hours, b. The trip was made only for a while, c. People who do not earn a living in a place or country he visited.

In tourism is also known as a tourist attraction, that is, everything related to tourism that encourages tourists to visit these destinations. Pitana states that the tourist attraction is related to the provision of appeal or attraction for tourists [17]. Its main locations mainly in tourist destinations, but in some cases it is also located in the transit area.

There are several types of Tourism which has been known, namely [16]:

- Cultural travel, that is, journeys undertaken on the basis of the desire to expand their way of life through visit to another place or abroad, studying the situation of the people, customs and their customs, their way of life, culture and their arts.

- Health Tourism, which is the journey of a traveler with the objective to exchange the circumstances and the environment in everyday where he lived for the sake of rest for him in the sense of physical and spiritual.

- Sports Travel, the tourists who travel with the purpose of exercising or was deliberately intended to take an active part in the Games in a place or country.

- Commercial tour, which included a trip to visit exhibitions and fairs for commercial purposes, such as industrial exhibitions, trade fairs and so forth.

- Travel Industry, which is a journey undertaken by a group of students or people to a complex or industrial area with the intent and purpose to hold a review or study.

- Maritime Travel, namely the many attractions associated with water sports, such as lakes, beach or sea.

- Tourism Nature Reserve, which is kind of travel which are commonly held by an agent or a travel agency specializing efforts by regulating travel to the place or area of nature reserves, protected parks, forests and mountain areas so that its preservation is protected by legislation.

- Travel Honeymoons, which is an organization of trips for newlywed couples on their honeymoon with special facilities.

\subsection{Creativity tourism}

Hermantoro [11] states that the term creative tourism is tourism activities that involve interaction of migrants, so that newcomers can learn, connect emotionally, socially 
on the lives of local people, so that they will become part of the local community itself. That definition gives an idea on the condition where travelers can feel a part of the development of the destination itself. This definition also provides creative tourism limits in the form of their perceived authentic experience rating, the participatory learning, interactive and informal, non-mass, and is closely linked with the local community.

Furthermore, it can be said that the definition of creative tourism is an experience of having 'that allow travelers to develop their creative potential. The characteristics of creative tourism are:

1. Theme relate to local cultural scene that includes among other cultural activities people, food, nature, art.

2. Informal/non-rigid and flexible

3. hand on involving visitors to learn interactively

4. Entries are limited to small groups or personal

5. The activities carried out in the faculty or workplace/workshop and not in luxury seminary room. This condition support to the authentic atmosphere and informal

6. Allow visitors explore their creativity so that the teaching curriculum is not limited strictly/flexible.

7. Support the sustainable tourism market with the market for upgrades/traditional skills of a community, and can utilize the infrastructure and facilities that already exist.

8. Being closer to the local community, including teachers/instructors and the surrounding community.

From the explanation of the concept, the author tries to make the theoretical framework of the study as follows:

\section{Research Methods}

This research use qualitative research methods, methods of qualitative research is a research method that is used to examine the condition of natural objects, (as his opponent was an experiment) where the researcher is as instrument key, data analysis is inductive, and qualitative research results further stresses the significance of the 


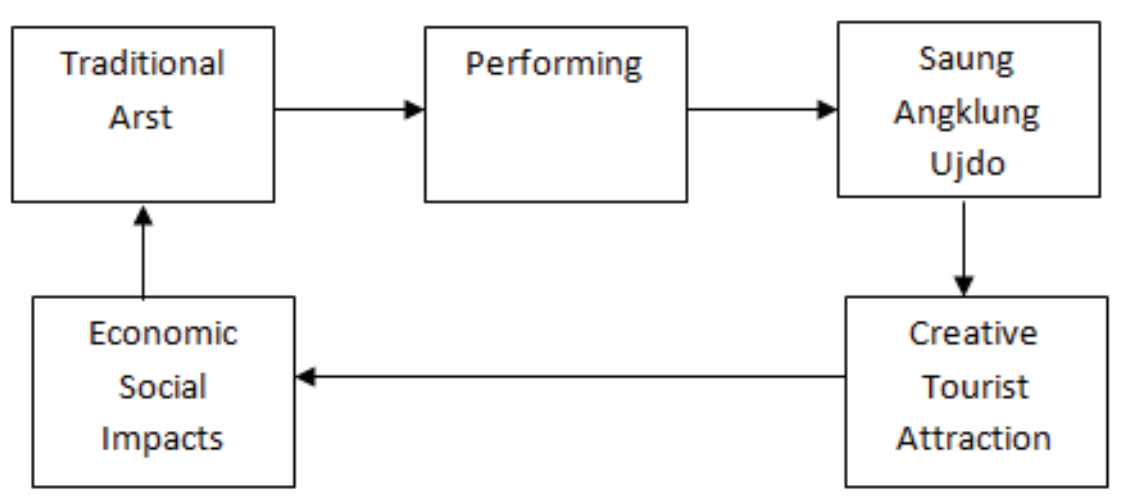

Figure 1: Framework Theory.

generalization [18]. Data needed in this research is data information on the performing arts in SAU. Data collection techniques in this study was obtained by observation in the SAU, interview, and literature study.

The data processing is done through several stages in accordance with the problem to be solved. The research problem is the transformation of the traditional arts appointment as cultural tourism appeal case studies Saung Angklung Udjo. In an effort to examine these problems required concepts such as concept art, the concept of tourism, creative tourism concept.

\section{Disscussion}

\subsection{The existence of Saung Angklung Udjo}

Saung Angklung Udjo (SAU) was founded in 1966 by Udjo Ngalagena and his wife Uum Sumiati. Ideals SAU is trying to realize the ideals of Mang Udjo namely 'Angklung as art and cultural identity of the plume'. SAU was established with the basic philosophy of mutual assistance is part of the Sundanese culture. An Entrepreneur Udjo an artist as well, he has a motto 'keep the old ones, treat the new ones'. Motto were developed in activities at Saung Angklung Udjo until today. Saung Angklung Udjo in Bandung precisely located in Jalan Padasuka No. 118, Bandung, West Java with a distance of 155 km from Jakarta.

Before it becomes a big as it is now, Saung Angklung Udjo just a small studio of 80 meters which is also the home of the founder of Saung Angklung Udjo Ngalagena Udjo. Improvement and expansion of the area was done in order to support the demand of tourists are progressively increasing. Saung Angklung Udjo now has an area of approximately 1 hectare complex. Although the area of land to grow but the location of the 
land is not changed from when still a small studio. The land is more widely used as open land, such as parking lots and parks. Most other land used as office space, guesthouse, performance hall, souvenir shop, a reception area, canteen, mosque, toilets, as well as the place of angklung manufacture. All activity or performance spaces reserved for tourists are concentrated in the front area. While the rear area is used for the training of performers and open green spaces.

\subsection{Performing art Saung Angklung Udjo}

Performing arts is the main activity and routine at SAU. Performances carried out every day in Bale Karesman. Schedule staging a performance at Saung Angklung Udjo divided into 4 time performances are at 10:00 to 11:30 o'clock in the morning, lunch at 13:00 to $14: 30,15: 30$ to $17: 00$ o'clock in the afternoon and evening at 18:30 to 20:00 pm. Performances morning, noon and night is tentative, that is if there are vacationers who come, at least 50 people, they can enjoy the show in the morning or afternoon. While the afternoon show is a show that is regular, referring to the show will go ahead regardless of the number of tourists present to watch. Performing this afternoon also called the Bamboo Afternoon Show is a concept originally came from the idea Udjo Ngalagena called Kaulinan Urang Overtime (a traditional game of society). Afternoon Bamboo Show is a legendary event that has existed from the 1970 .

This afternoon show that is usually watched by the general rating, which does not come as a group or foreign travelers. Based on information obtained from interviews with various speakers and experienced researchers themselves, each show consists of several material events (repetoar) is a demonstration of the puppet show, helaran, traditional dance (mask dance and peacock dance), angklung mini, arumba, Angklung Pa-Daeng, play angklung, angklung orchestra and ends with dancing together.

The material is used as an event appeal by SAU managers in attracting tourists. This performance was led by an MC (Master of Ceremonies) who will guide the course of the show. To be able to watch the entire series of the play, the audience needs to pay USD $60,000.00$ for domestic travelers to $\$ 120,000.00$ for foreign travelers. These costs are not just for the play alone but viewers also get a small souvenir souvenirs angklung tied with black threads that resemble a necklace and a welcome drink in the form of wedang bandrek, mineral water or ice lolly. Here is the performing arts are presented Saung Angklung Udjo as creative tourism appeal. 


\subsection{Wayang Golek}

Puppet (Wayang Golek) is a typical art Sundanese people, which stages plays wooden dolls that resemble the human body complete with costumes. At first, the wayang golek performing staged at traditional ceremonies, such as the village clean ceremonies, ngruwat, turn of the head of the region and others.

Understanding the puppet itself can refer to the shadows, the doll or the show as a whole. As a shadow, the puppet is a reflection of human life. Puppet show was created based on the stories of human life. The dolls are driven by a puppeteer to tell the tale. The puppet is a show. As a show, puppet show is a combination of various elements, visual and non-visual combined, and playing together to form a complete show. Viewed from the side of philosophy, puppet word meaning a shadow, a reflection of the nature of the human psyche, such as anger, righteousness, greed, wisdom and so forth. Each puppet performances certainly carry a moral message that we always adhere to the Creator and to do good to others.

In general, staging puppet show lasted more than 7 hours, that is, at night from 21:00 to 04:00 o'clock. In SAU puppet show only just shown the demonstration only as a demonstration of how the puppet talking, dancing and fighting.

Before the puppet story begins, $M C$ first introduced to the audience mastermind who was called by the term Ki Dalang. This is where the puppeteer's face can be seen before the end of which he sat behind a table covered with a cloth. Puppeteer puppets accompanied by some music players behind him. The music that was played this made the atmosphere more lively and more dramatic. Musical accompaniment is able to dramatize the story that is being played by puppeteer that increasingly animates the audience and enjoy the story as if entered into, performed by puppeteer.

Position mastermind address an audience but was prevented by gedebog (trunk) of banana trees underneath by a cloth cover. Gedebog linings serve to plug puppet show. Dalang also played kecrekan (some metal plates which, when pitted reads Crek-Crek) is right in front of the feet of the puppeteer. Kecrekan are also used to dramatize the story, for example, when puppeteer hit the scene, it will emit kecrekan puppeteer with his feet. Sounds kecrekan the touch of the feet of the puppeteer progressively increased his performances, as the puppet-puppet show as the description of human life in the world.

The concept of a puppet show at Saung Angklung Udjo only show demonstrations (several scenes as a demo) of the arts. This demonstration is only showing some interesting scenes. Puppet show usually begins with a prologue delivered by Ki Dalang 
using Sunda language. Prolog is also called the nyandra in the language of puppet art. At the time of the prologue is the mastermind explains the title of what stories will be presented at the show, the scene of what will be sung, the kind of environment that is displayed as in the scene, or perhaps also scenes of non-formal outside the kingdom. He also how the inner atmosphere puppet characters to be displayed, the scene happy, sad or indifferent.

After delivering the prologue, the mastermind will continue the story by playing two puppets that are mutual dialogue. These dialogues in a language called the Antawacana puppet art. Dalang figures voiced puppet show on the stage in accordance with the character. Ki Dalang just shows how the puppet show characters talk and move the puppet's body member, such as a fight scene, a scene jogged, hips scene, fall scenes, and so forth. Ki Dalang seek to incorporate the essential elements in the art of puppetry, like sabetan, storytelling, puppetry literary, musical, bojegan (jokes), and the shape of the puppet itself.

Sabetan is a visualization of the movement of puppet including dancing and fighting style. This element is able to describe the skill of the puppeteer puppet plays. Dalang is required to have the ability to display motion puppet with cunning and full of inspiration. Good skills will produce an interesting visualization and communicative impression to the audience. Sabetan an important aspect in a puppet show. Slashes interest will certainly influence the impression the audience in assessing the puppet show.

In the world of puppetry, there are three types of play presented by the mastermind, that strain, splinter, and carangan. The strain is a story that comes from the Ramayana, Mahabharata, Babad Lokapala. Telling the story to story lines require a minimum of 7 hours even up to the day and night. The play strains are usually delivered on special occasions such as a wedding or a circumcision celebration. Splinter is a play that takes up most of the principal sources (strain) and the other part is an additional story. While carangan is a play that has been separated from the principal source of the story but several figures deemed necessary remains taken from the principal source of the story. The play is usually displayed at Saung Angklung Udjo is a form of play splinter and carangan. Staging puppet show tells the story here is not who can spend hours and hours so the stories presented a bouquet of puppeteer. Forms play carangan contextually splinter and can be tailored to the issues that are going on, for example, the issue of political, economic, social and humanities.

The story was carried in staging puppet show is a light and humorous stories that invite laughter of the audience on the sidelines of the show. Dalang always insert 
messages of moral or social criticism in the demonstration of this puppet show. The story also varied and tailored to who the audience (tourists) are watching. In addition to the puppet characters are played, Ki Dalang always feature puppet characters that are not playable in the form Janturan. Janturan is a series of puppet show that is not played, is placed on the right and left of the table show, and plugged in banana leaves. Janturan usually grouped with the character of the figures puppet show. People who have good character and evil characters. Character played normally play 'Cepot'. Presented with a sense of humor. All the spectators who understand the plot laughing viewed staging for approximately 15 minutes this.

Puppet show is so loaded with educational values. Educational messages and moral message very clearly visible. There are about moral education, there is a reality in life that there are good and there is evil, surely goodness over evil, special messages for the schoolboy segments, that is, do brawl, do drugs, study hard, and so forth. There are interesting in the demonstration puppet show at SAU. If in all the standard puppet puppeteer did not open the cloth that covered the position mastermind, then at SAU actually opened. This is explained by Chandra who is in charge of the creative team as follows:

Puppet show it is only a demonstration, because it is a demonstration that more to the introduction and education, the show is made as easy as possible and as simple as possible. Nevertheless, the principles contained in the puppet show retained, in other hand, special messages both implicit and explicit in the story that brought Ki Dalang also greatly highlighted as a moral and other virtues.

Puppet as a performance art aspect that has manifested in the form of puppets, music and other performances supporting element. Each element in the puppet show has its own meaning and purpose that each different from one another. All these elements together and then become a show piece. In puppets, elements of art visible through any engraving on the body and face of a puppet to describe the characteristics, properties, status and disposition of puppets. Each carving has a meaning and a purpose.

In music, art elements contained in any accompanying strains of gamelan puppet show. Music became an important element to liven up the show. To make the audience dissolve into stories or scenes of the show.

In the show elements, artistic elements contained in any lighting, decoration, storylines, and so on. All these elements make the show puppet prototype to be interesting and not monotonous. Spectators getting late into the story and the show became a good show. 
Aspects of art in this performance needed to liven up the show so as to create an interesting show audience to continue listening. Each element in the puppet show is art. Art of motion, art of music, art lighting and so on. Each of these arts support each other and support each other, so as to create a show that is intact.

\subsection{Helaran}

According to $M C$ and a synopsis of the show, researchers learned that helaran is one of the traditions of West Java community in the form of a procession in the streets which is a party of the people or parties offering gratitude. In general, long ago helaran ceremony played to accompany the traditional circumcision ceremony/groom during the ceremony of circumcision and the rice harvest. Angklung type used in this tradition is angklung barreled selendro or pentatonic. Helaran itself played cheerfully because it is intended to show gratitude.

Staging begins with the inclusion of four people carrying the flag, followed by four dancers kuda lumping and pageantry wedding circumcision. In staging helaran, a child is removed and paraded by train pelvis. Then there are also dances played small children with cute and plain style that invites the audience laugh.

The number of children involved in the game more than 30 children crowded so boisterous voice and cuteness of children makes the show very interesting. Helaran displayed for approximately 10 minutes. In this helaran show, looks cheerful children dance, play the angklung, carrying flags, sustain procession (train pelvis), demonstrate martial arts movements and there is one boy who plays a boy who runs circumcised. Circumcised child is paraded around the stage while waving to the audience and then train the pelvic lowered amid stage. The next scene her friends to her and they dance together.

All children wear colorful outfits so impressed stage a colorful, lively, and festive. This show is packaged attractively so that the impression happy and pleased for anyone watching. After the dancing, the little boy who was circumcised train back up to the pelvis and then paraded back.

Meaning that wants to be expressed in the show helaran circumcision is a sense of happiness, togetherness and solidarity. Performances helaran at Saung Angklung Udjo the modified by adding attractions dance that resembles martial arts performed by boys, girls duty to menyayi and rang the angklung, and boys who already more mature tasked to hold the chair for a small child who paraded. 
According Udjo Pearls, helaran event was inspired by the childhood experiences of their parents. In Cicalung, the village where the environment turns Udjo grew very thick with the traditional arts. One of his childhood memories that helaran event. The kampong, if there are children circumcised/uncircumcised usually like paraded around the village with music and other simple tools.

\subsection{Traditional dance}

There are two kinds of traditional dances that are held in SAU, that is, mask dance and peacock dance.

\subsubsection{Mask dance}

Mask dance is a classic dance mask Kandaga that style mask dance series that tells the queen Kencana Parahyangan Wungu pursued by King Minakjingga were crazy about him. In demonstration of this dance is only a trailer of the patterns of classical dance mask Kandaga. This dance is divided into two rounds. The first round (without a mask) and second half (wearing a mask). The mask represents the character of the human disposition. Interestingly, the mask is not attached to the face but no rubber bitten by the dancers so it is necessary to show the seriousness of the dancers dancing to the finish in order to mask that is used cannot be separated.

\subsubsection{Peacock dance}

Peacock Dance is a dance that is a manifestation of the beauty and the beauty of a peacock. Create peacock dance is a creation depicting a peacock who was chatting in the garden. Peacock dance is one of the new creations dance from West Java. There are five dancers who are all women, wearing colorful and resemble a peacock. Peacock dance is a dance that used to welcome guests. Peacock Dance illustrates how a male peacock peahen attract attention by showing off long tail feathers.

\subsection{Mini Angklung}

Mini Angklung performance, angklung small size which can serve as ornaments and musical instruments. This minimalist angklung performances usually played by children by presenting a children's song that is popular in many countries, for example the 
song dolls, Bed Kenanga in different languages, The Song of Do Re Mi and Cockatoo Bird. When playing the angklung, the expression of the players adapted to the songs sung. Teamwork highly visible and their faces while playing still exudes a smile to the audience

\subsection{Arumba}

Arumba stands strains of Alunan Rumpun Bambu, it is a traditional musical instrument made of bamboo bertangga diatonic scales. The combination of various musical instruments from bamboo produce harmonious tones and dynamic. Arumba created by Muhammad Burhan (Ujang Burhan) in 1965 which was later developed in the SAU 1970. Many of the songs using music arumba not only folk songs of West Java, even pop and dangdut music can also be presented with arumba. A set of musical equipment arumba consists of: A set of melodic angklung 3 tube, 4 pieces calung-chromatic and diatonic large bamboo.

\subsection{Angklung Pa Daeng (Angklung Music Parade Nusantara)}

Angklung Pa Daeng is angklung that base on do-re-mi. Originally native angklung is less known, is not barreled and used as a means of rhythmic music, but after Daeng Soetigna modifying the barrel of the do-re-mi in 1938 angklung can be used to play songs of national and foreign songs. Use of this is packaged in Padaeng angklung performances archipelago musical parade at SAU.

\subsection{Interactive Angklung}

Interactive Angklung Performance art is angklung play sessions involving the whole audience (Figure 1). This session is organized in such a way to interact more with the audience. In this interactive angklung performance, each spectator is given a single fruit maing angklung. Angklung reads one of eight diatonic tones that exist. After all the spectators certainly got angklung, $M C$ invite someone who will lead/became conductor in play angklung. These games are usually led by the son Udjo Ngalagena.

In some performances, I see this game led by Sam Udjo, Yayan Daeng Udjo and Udjo. Leaders must first show to teach the basics of playing angklung, are signs for each tone. Angklung has two tubes, large and small. Large tube sections should be put on the right, while small on the left. How to hold them are holding angklung in the 
middle with his left hand. The right hand holds the bottom angklung, angklung shake it will sound a melodious of two tubes angklung. The method used by the leadership to play the angklung in bulk is by using the Hand sign and read notation numbers written on the front of the stage.

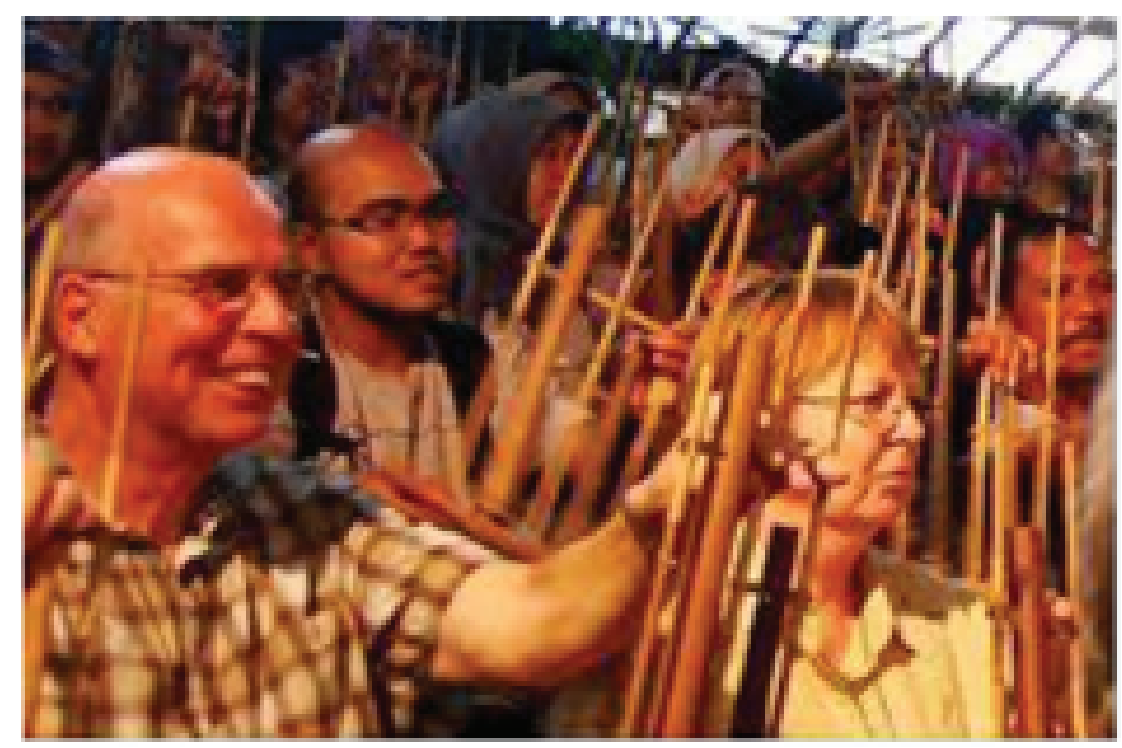

Figure 2: The audience are enthusiastic to play the Angklung Music.

At a show, I happen to get angklung He pitched so that if the leadership/conductor signaled to tone la, then I had to wiggle the angklung that I hold. Conductor provides guidance using two languages, Indonesian and English. After teaching the signs that are used on each tone, the conductor began to invite the audience to play a few songs. The viewers seem very keen to play the angklung. Everyone looked at the hands of the conductor who gives the sign, waiting for when they have to ring the angklung. Furthermore, the conductor will lead the audience to a rendition by moving his hands, which symbolizes a certain tone. Live audience follows the hand sign of the conductor. The result is a song that is more successful older brother played and songs militia; rainbow.

\subsection{Orchestra Angklung}

After Angklung Interactive, followed by Angklung Orchestra. Angklung orchestra is the work Udjo Daeng. On stage there are usually 8 angklung players, 4 male and 4 female or it could be more than that amount, as needed. They each hold one angklung circuit consisting of a few notes, and everybody is forced to play more than 7 angklung. So a player angklung orchestra should play a set of angklung whose number one octave. 
The game is also accompanied by a drum, a bass guitar, and a gamelan. Angklung played all bertangga diatonic scales so that it can play any song, including songs of the west.

\subsection{Dancing together}

At the end of the show, the performers will go again to the stage and invites visitors (all audience) to have fun and dance together. This is the end of a whole series of performances at SAU (Figure 3). All the children go to the stage, each took one of the spectators at random to be invited to dance along. First the audience are invited to play a very long serpent, circling the stage, after which the audience dancing along as directed by children. At the same time MC closed the ceremony.

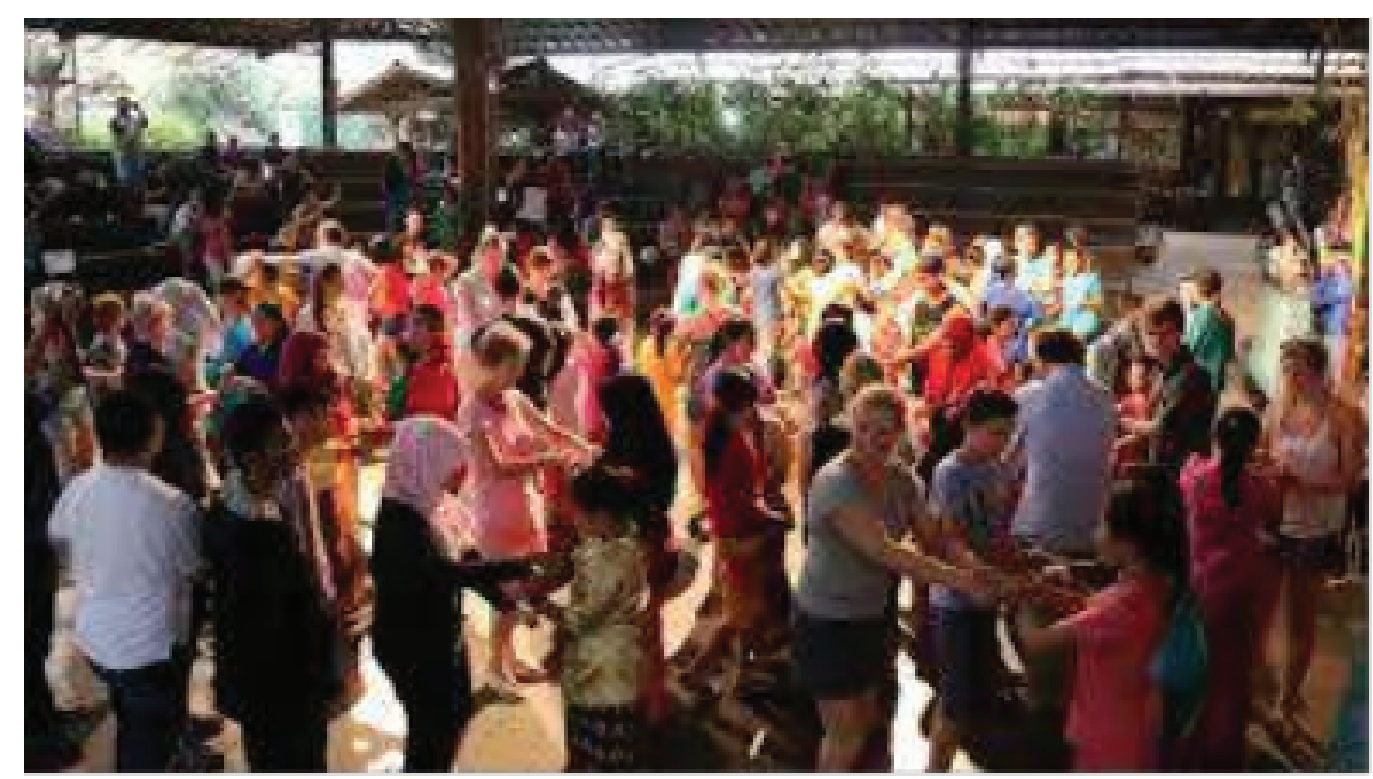

Figure 3: Visitors and SAU's artist dance together.

Based on observations and discussions with managers show at SAU and quoting (Sudarsono RM: 1999) that the performing art is art in which the actions of individuals or groups in a particular place and at a particular time is a job. It can happen anywhere, at any time, or for a long time. Performance art can be any situation that involves four basic elements are: time, space, the artist and the relationship between performers and audience.

In the process of the show include the essential elements that must exist, namely players (performer), audience (audience), message (idea). All three are interwoven or interaction that a deliberate and conscious. 
In general the performing arts in SAU is optimal in the making. For example, about the time of the show. As explained at the beginning of that time performing arts at SAU is clear that the staging of the show schedule at Saung Angklung Udjo divided into 4 time performances are at 10:00 to 11:30 o'clock in the morning, lunch at 13:00 to $14: 30,15: 30$ to $17: 00$ o'clock in the afternoon and evening day at 18:30 to 20:00 pm. Performances morning, noon and night is tentative, that is if there are vacationers who come, at least 50 people, they can enjoy the show in the morning or afternoon. While the afternoon show is a show that is regular, referring to the show will go ahead regardless of the number of tourists present to watch.

Then for the performance space, which is generally used bale Karesman as a place for the performing arts in SAU. Is the venue at SAU. Here visitors will be treated to a bamboo evening, dance performance, angklung, arumba, orchestra, and puppets. The place resembles a massive stage with terraced sitting system (the stands). There is one main stage set complete with bamboo musical instrument, band, puppets, gamelan, and sound system. This place can accommodate about 200 tourists. Bale Karesman also equipped with lighting good performances so as to further liven up the show. The venue can also be done in other places in the area still SAU to meet special requests such as in the area gathering area. In this place the visitors, especially the group who want to order an entree buffet menu can gather and enjoy the natural feel of Sundanese village diorama at SAU. Are semi-outdoor decorated lamps - lamps hanging from the bird cage and fitted table - bamboo stools. There is also a mini stage for additional performance or other purposes.

Then to the player (performer), the number of players in the performing arts SAU for approximately 50 players per show consists of some of the smallest age of 4 years of age until adulthood. Most of the players are students who participate in the SAU arts training. If on the day of performance art SAU held up to 4 times, usually every session players are also different. This is precisely what became one of Pull yourself when tourists visit and enjoy the performing arts so it is not boring.

Then in terms of the audience (the audience), SAU became one of the tourist destinations that attract tourists to visit. Based on data from the HRD SAU in 2014 the number of local tourists who visit SAU reached 120 thousand tourists, and the number of foreign tourists reached 20 thousand people. Of course this is very encouraging, on the one hand SAU can bring in foreign exchange, on the other the preservation of culture, especially the performing arts can also participate Sundanese culture well preserved in the midst of the onslaught of globalization. 
No less important in the performing arts is the relationship between the players (performer) with the audience (an audience). Art shows in SAU between players and spectators almost no distance. Master of Ceremonies (MC) which governs the whole series of events performing arts. Two-way communication is built up through the MC to make the audience seemed to be part of a performance art itself. Using two languages, Indonesian and English, in addition interspersed with other languages in accordance with the tourists present performances make the atmosphere more liquid and tasty. Relationships players and spectators are felt when the $M C$ or the player to invite the audience to ask questions, answer questions, sing together, dance together, play angklung together, and all of them are soluble in one unity through art performances. Almost in all the performing arts in the SAU, featuring performances by the entire cast optimal and compact, and while the player's face still exudes a smile to the audience. The audience was very entertained and gain memories that are unlimited in price.

The moral of the performing arts in SAU them through the art of puppet show is that we always adhere to the Creator and to do good to others. Who planted the goodness he will reap happiness and whoever committed the crime then he akana suffer the consequences. Educational messages and moral message very clearly visible. There are about moral education, there is a reality in life that there are good and there is evil, surely goodness over evil, special messages for the schoolboy segments, that is, do brawl, do drugs, study hard, and so forth. Through the performing arts such as playing angklung, dancing with its moral message is gratitude to the Almighty, love to sesame, love to Nature, and we are the same.

Saung Angklung Udjo, has been optimized in presenting performing arts that originally bore into a performing arts that attracted tourists. The performing arts successfully packaged with a relatively short time, a solid, entertaining and interactive. Served with bilingual performing arts, namely Indonesian and English bahada, presenters also say a few words in Sundanese so that visitors can recognize. The players (the performers) are very well versed in bringing the performing arts and also explain it to every tourist that walked pertujukkan attractive. The players are trying to win the hearts of travelers in a way to congratulate dating and thanks to various languages in the world considering the tourists present made up of various nations in the world and not only domestic tourists or tourists only.

Performing Arts Saung Angklung Udjo consisting of demonstration Marionette Puppet, Helaran, traditional dances such as Tari Merak and Mask Dance, Calung, Arumba, Angklung Pak Daeng Angklung Playing Together, Angklung Orchestra, Angklung Jaipong and Dancing Together. The show is packed with a very different and fun 
because of the show invites visitors to participate, namely Angklung play together. Visitors are taught to play Angklung easily and quickly so learn Angklung looks fun. Moreover, the absence of children involved in this show, the more enliven the atmosphere, they look cheerful when doing.

\section{Conclusion}

From research conducted at Saung Angklung Udjo, based on interviews and studies related literature, researchers can conclude the following:

- The art shows in Saung Angklung Udjo consists of Marionette Puppet, Helaran, Traditional Dance (Mask Dance, Peacock Dance), Angklung Mini, Arumba, Angklung Bulk Nusantara, Playing Angklung together, Angklung orchestra, and dance together.

- Saung Angklung Udjo have transformed by optimizing the performance art of Sundanese culture that is by packing into a performing arts are creative, innovative, interactive without abandoning tradition.

- Saung Angklung Udjo pack performing arts performances by optimizing the time so it was not too long and boring. Art pertujukkan packaged in short, dense, entertaining, and interactive, served with bilingual namely Indonesian and English.

- In the performing arts, performing arts SAU has shown complete with elementelemenya that no player (performer), audience (audience), message (idea) and the third is the fabric or interaction that converges deliberate and conscious.

\section{Suggestion}

Performing arts at Saung Angklung Udjo, if you want not boring and can survive in the middle of the swift currents of globalization, must always find new ways to be a creative, innovative, interactive so as to produce the packaging art performances that entertain without leaving the tradition and interested tourists as an alternative creative tourism destination.

\section{References}

[1] Jim Ife, "Community Development In An Uncertain World,". New York. USA. 2013 
[2] M. Jamil, Mukhsin Khoirul Anwar and Abdul Kholiq, "Faktor-Faktor Yang Organisasi Seni Pertunjukan,". Jakarta: Pustaka Binaman Pressindo. Jamil, 2011

[3] Supriadi, Dedi, 1994. Kreativitas Kebudayaan dan Perkembangan Iptek. Bandung: Alfabeta

[4] Azali, Kathleen. Ludruk: Masihkah Ritus Modernisasi? Jurnal Lakon Vol. 1 No. 1 Mei 2012 UNAIR. Surabaya

[5] http://female.kompas.com/read/2009/Puluhan Kesenian Tradisional Indonesia Terancam Punah, Jumat, 24 April 2009

[6] Pratiwi, Annisa. 2013. "Pelestarian Angklung Sebagai Warisan Budaya Takbenda Dalam Pariwisata Berkelanjutan Di Saung Angklung Udjo", Bandung. Tesis Universitas

[7] Asharinne, Loulasela, 2012. Identifikasi Proses Pengembangan Inovasi Dalam Cambridge University Press

[8] Milyartini, Rita A \& Chaedar Alwasilah. Saung Angklung Udjo Sebuah Model transformasi Nilai Budaya Melalui Pembinaan Seni Untuk Membangun Ketahanan Budaya. FPBS Universitas Pendidikan Indonesia, Jurnal Integritas, Vol. 1 No. 1, Desember 2012

[9] Budiman Mahmud Mustofa,. Kreativitas Udjo Ngalagena: Studi Keberhasilan Pengembangan Kreativitas Saung Angklung Udjo (SAU). Jurnal Vokasi Indonesia. Volume I, Januari-Juni 2015

[10] Danandjaja, James. 2002. Folklor Indonesia. Jakarta. Pustaka Utama Grafiti

[11] Hermantoro, Henky. 2011. Creative-Based Tourism: Dari Wisata Rekreatif.

[12] Damanik, Janianton. 2013. Pariwisata Indonesia: Antara Peluang dan Tantangan.

[13] Permas, A., C. Hasibuan-Sedyono, L.H. Pranoto, dan T. Saputro. 2003. Manajemen Pertunjukan Indonesia, 1999, 378-381.

[14] Haviland, William A. 1993. Antropologi. Jakarta. Penerbit Erlangga

[15] Soedarsono RM, Seni Pertunjukan Indonesia dan Pariwisata. Bandung: Masyarakat Seni

[16] Pendit, N.S. 1990. Ilmu Pariwisata: Sebuah Pengantar Perdana. Jakarta: Pradnya Paramita

[17] Pitana, Gde. 2009. Pengantar Ilmu Pariwisata. Yogyakarta: Andi Offset

[18] Sugiyono. 2008. Memahami Penelitian Kualitatif. Bandung: CV. Alfabe 